\title{
PENDIDIKAN DAN PERTUMBUHAN EKONOMI ANTAR KABUPATEN DAN KOTA DI PROVINSI JAWA BARAT
}

\author{
Adhitya Wardhana ${ }^{1}$ \\ Bayu Kharisma ${ }^{2}$ \\ Zahra Ikhlasni ${ }^{3}$
}

\begin{abstract}
Fakultas Ekonomi dan Bisnis Universitas Padjadjaran, Jawa Barat, Indonesia ${ }^{1,2,3}$
Email: adhitya.wardhana@unpad.ac.id ${ }^{1}$
\end{abstract}

\begin{abstract}
The education sector plays an important role for the development of a region. The measure of the success of improving the quality of human resources is by looking at the mean of year schooling. The increase in the mean of year schooling reflects the success of education policies in educating the public. This study analyzes the effect of mean of year schooling, life expectancy, government spending in the education and health sectors on economic growth in 26 districts / cities of West Java for the period 2012 - 2017. The method used is the Panel Data Regression Model. The results showed that all variables used in this study had a positive influence on economic growth in 26 districts / cities of West Java Province, where the mean of year schooling was the most statistically significant variable on economic growth in West Java Province.
\end{abstract}

Keywords: GRDP; Mean of Year Schooling; Life Expectancy; Government Expenditures; Economic Growth

\begin{abstract}
ABSTRAK
Sektor pendidikan memberikan peranan penting untuk pembangunan suatu wilayah. Ukuran keberhasilan peningkatan kualitas sumber daya manusia yaitu dengan melihat rata-rata lama sekolah. Peningkatan rata-rata lama sekolah mencerminkan keberhasilan kebijakan pendidikan dalam mencerdaskan masyarakat. Penelitian ini menganalisa pengaruh rata-rata lama sekolah, angka harapan hidup, pengeluaran pemerintah dalam sektor pendidikan dan kesehatan terhadap pertumbuhan ekonomi di 26 Kabupaten/Kota Jawa Barat periode 2012 - 2017. Metode yang digunakan adalah Panel Data Regression Model. Hasil penelitian menunjukkan bahwa semua variabel yang digunakan pada penelitian ini memiliki pengaruh yang positif terhadap pertumbuhan ekonomi di 26 Kabupaten/Kota Provinsi Jawa Barat, dimana rata lama sekolah merupakan variabel yang paling signifikan secara statistisk terhadap pertumbuhan ekonomi di Provinsi Jawa Barat.
\end{abstract}

Kata kunci: PDRB; Rata-Rata Lama Sekolah; Angka Harapan Hidup; Pengeluaran Pemerintah; Pertumbuhan Ekonomi 


\section{PENDAHULUAN}

Indikator keberhasilan ekonomi dari suatu wilayah melalui perkembangan aktivitas perekonomian yang sering dikenal dengan pertumbuhan ekonomi. Faktorfaktor yang mempengaruhi pertumbuhan ekonomi adalah sumber daya manusia, sumber daya alam, teknologi, ilmu pengetahuan dan budaya. Proses pembangunan didapat dari kinerja sektor pendidikan, kesehatan dan pendapatan yang sering disebut sebagai pembangunan manusia. Tujuan dari pembangunan untuk menciptakan lingkungan yang memungkinkan rakyat untuk menikmati sehat, umur panjang, dan menjalankan kehidupan yang produktif (UNDP, 1996). Berdasarkan Undang-Undang Dasar 1945 dan Pancasila pembangunan pada hakekatnya merupakan upaya untuk mewujudkan tujuan nasional bangsa Indonesia yang maju, mandiri, sejahtera, berkeadilan.

Pertumbuhan ekonomi merupakan indikator paling penting untuk mengukur keberhasilan dalam upaya meningkatkan kualitas hidup manusia. Pencapaian pertumbuhan ekonomi pada tahun 2017 ini mengalami penurunan karena pada tahun 2016 pertumbuhan ekonomi Kabupaten/Kota Provinsi Jawa Barat sebesar 5,66\% (Badan Pusat Statistik, 2017). Dapat dilihat dari Grafik 1 bahwa pertumbuhan ekonomi di Kabupaten/Kota Provinsi Jawa Barat pada tahun 2017 mencapai 5,29\%, namun pertumbuhan ekonomi masih terjadi ketimpangan. Ketimpangan antar daerah menunjukkan proses pemerataan pembangunan belum berjalan secara optimal. Pertumbuhan ekonomi yang tertinggi di Kabupaten/Kota Provinsi Jawa Barat yaitu di Kota Bandung sebesar 7,21\%. Selanjutnya, pertumbuhan ekonomi yang terendah di Kabupaten/Kota Provinsi Jawa Barat yaitu 
Kabupaten Indramayu sebesar 1,45\% sedangkan Provinsi Jawa Barat sebesar $5,29 \%$.

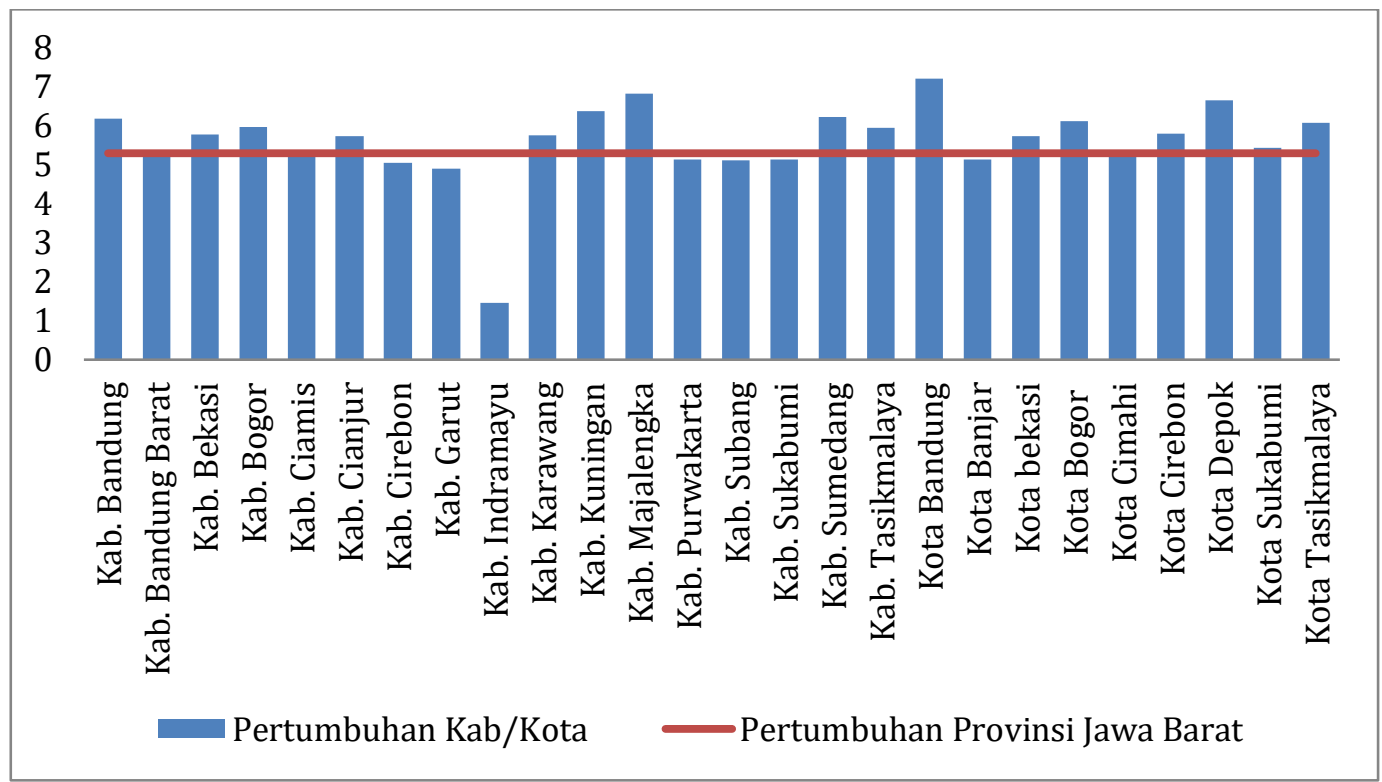

Sumber : BPS (berbagai edisi)

Grafik 1.

Capaian Pertumbuhan Ekonomi Kabupaten/Kota dengan Provinsi Jawa Barat Tahun 2017

Pertumbuhan Ekonomi di Kabupaten/Kota Provinsi Jawa Barat pada tahun 2017 menjadi permasalahan yang harus diperbaiki oleh pemerintah. Hal ini terlihat pemerataan modal manusia yang belum merata. Oleh karena itu, peningkatan sumber daya manusia yang lebih merata diperlukan peran pemerintah, antara lain mengeluarkan anggaran biaya sektor pendidikan. Salah satu langkah kebijakan di era Desentralisasi Fiskal yaitu dengan adanya kebijakan perimbangan keuangan antara pusat dan daerah yang memiliki tujuan untuk mencapai pemerataan pembangunan ekonomi di seluruh daerah, dimana adanya perimbangan keuangan antara pusat dan daerah akan mendistribusikan anggaran pendidikan untuk mencerdaskan masyarakat. 
Rata-rata lama sekolah yaitu penduduk yang berusia 15 tahun ke atas yang sudah menempuh semua jenis pendidikan formal yang pernah dijalani. Rata rata lama sekolah menujukkan jenjang pendidikan yang pernah atau sedang diduduki oleh seseorang selain itu semakin tingi angka rata-rata lama sekolah maka semakin lama atau tinggi jenjang pendidikan yang ditamatkannya (Badan Pusat Statistik, 2019). Rata-rata lama sekolah menjadi standar pemerintah daerah dalam melihat keberhasilan pendidikan. Keberhasilan pendidikan akan mempengaruhi terhadap peningkatan pertumbuhan ekonomi. Penentu dasar pertumbuhan ekonomi suatu wilayah yaitu pendidikan selain itu modal manusia juga memiliki pengaruh yang kuat terhadap pertumbuhan ekonomi suatu wilayah (Teixeira \& Queirós, 2016).

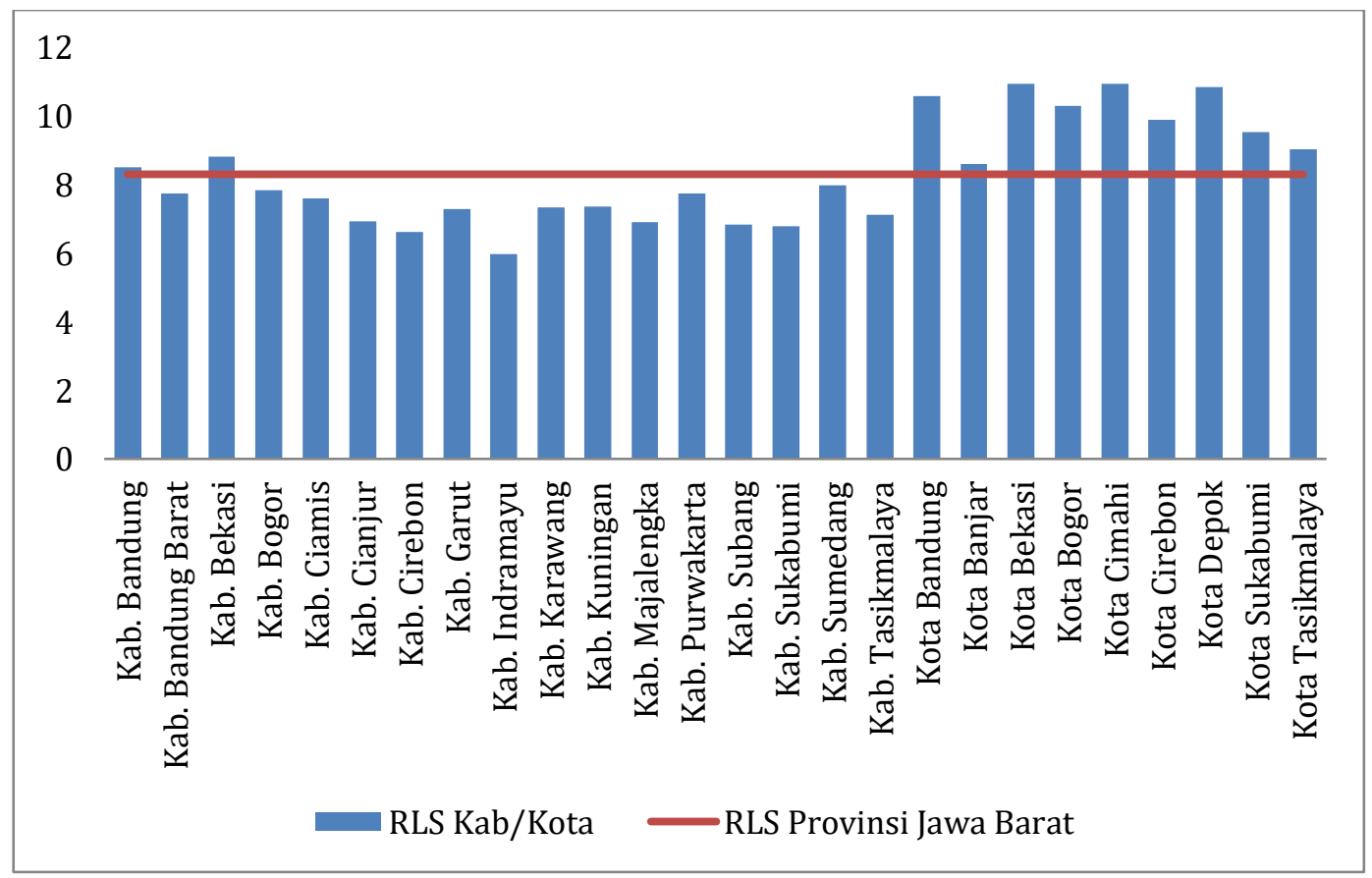

Sumber : BPS (berbagai edisi)

Grafik 2.

Capaian Indikator Pendidikan (Rata Lama Sekolah)

Kabupaten/Kota dengan Provinsi Jawa Barat Tahun 2017 
Pada Grafik 2 menunjukkan bahwa rata-rata lama sekolah tertinggi di Kabupaten/Kota Provinsi Jawa Barat pada tahun 2017 adalah Kota Bekasi sebesar 10,93 tahun dan Kota Cimahi sebesar 10,93 tahun, sedangkan yang memiliki tingkat terendah yaitu Kabupaten Indramayu sebesar 5,97 tahun. Fasilitas pendidikan yang lengkap merupakan salah satu kesadaran pemerintah daerah maupun pusat akan pentingnya pendidikan. Upaya perbaikan kinerja pembangunan pendidikan terus ditingkatkan, namun beberapa indikator di Kabupaten/Kota Provinsi Jawa Barat belum menunjukkan kinerja yang optimal dan hanya beberapa daerah saja yang sudah maksimal pencapaian program pendidikan wajib belajar sembilan tahun. Secara keseluruhan masih ada beberapa Kabupaten/Kota di Provinsi Jawa Barat dibawah angka rata-rata lama sekolah Provinsi Jawa Barat yang mencapai 8,14 tahun.

Angka harapan hidup $(\mathrm{AHH})$ pada waktu lahir merupakan rata-rata perkiraan banyak tahun yang dapat ditempuh oleh seseorang selama hidup, dan kualitas hidup yang mampu dicapai oleh penduduk tertentu. Angka harapan hidup (AHH) menentukan angka harapan hidup di suatu wilayah, dimana angka harapan hidup didaerah satu dengan lainnya akan berbeda (Badan Pusat Statistik, 2019). Daerah yang memiliki AHH tinggi, maka daerah tersebut memiliki tingkat kesehatan yang lebih baik dibandingkan daerah lainnya. Penelitian Ngangue \& Manfred (2015) menjelaskan bahwa adanya peningkatan angka harapan hidup memiliki pengaruh positif terhadap pertumbuhan ekonomi. 


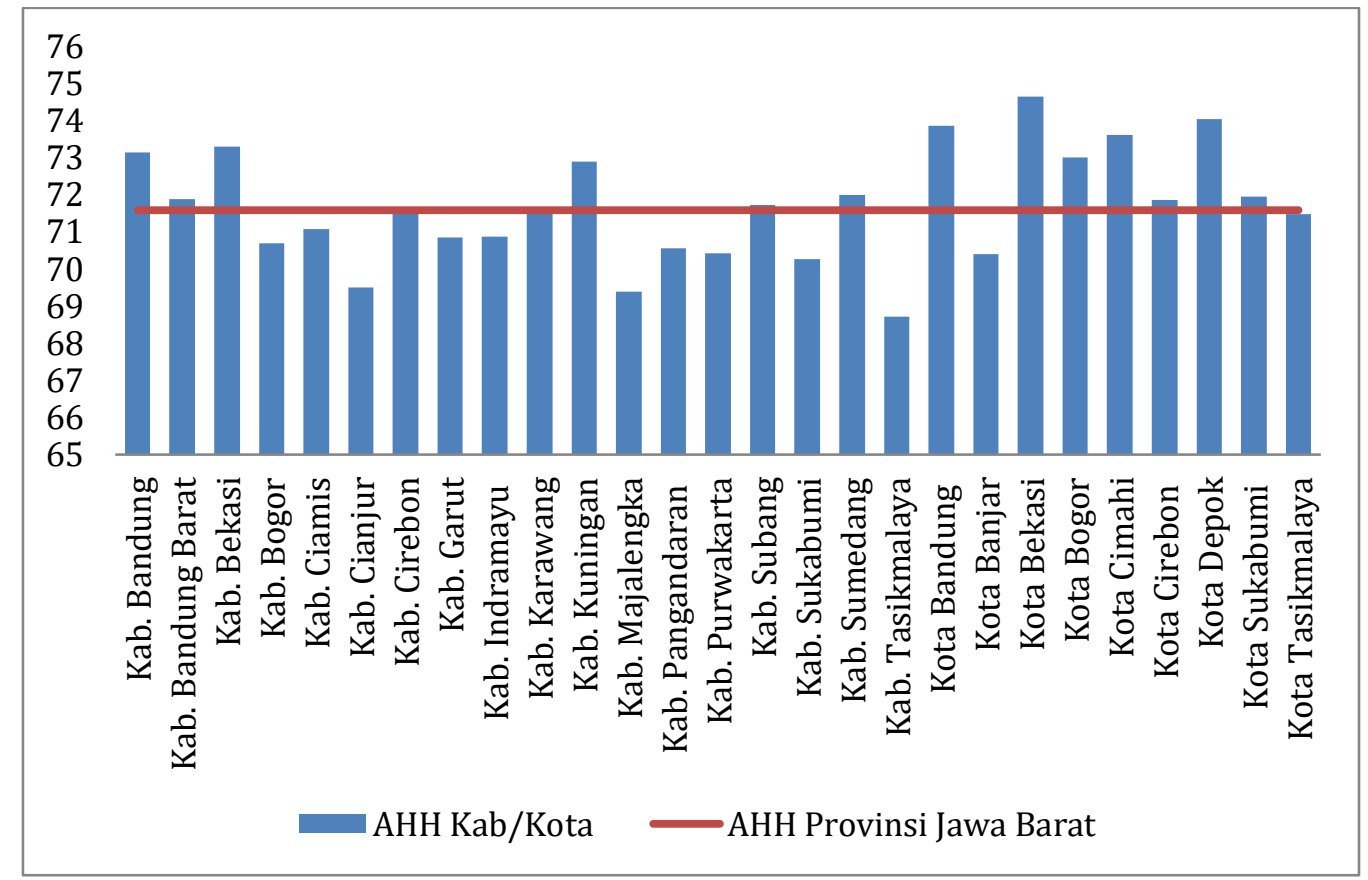

Sumber : BPS (berbagai edisi)

Grafik 3.

\section{Capaian Angka Harapan Hidup Kabupaten/Kota dengan Provinsi} Jawa Barat Tahun 2017

Pada Grafik 3 menunjukkan bahwa angka harapan hidup (AHH) di Kabupaten/Kota Provinsi Jawa Barat hanya beberapa daerah memiliki angka harapan hidup diatas 71,2 tahun dan masih ada juga sebagian daerah yang belum mencapai angka harapan hidup Provinsi Jawa Barat. Angka harapan hidup tertinggi di Kabupaten/Kota Provinsi Jawa Barat adalah Kota Bekasi yaitu sebesar 74,63 tahun, sedangkan angka harapan hidup terendah adalah Kabupaten Tasikmalaya yaitu sebesar 68,7 tahun. Keberhasilan kesehatan masyarakat dapat dari pengaruh pengeluaran pemerintah daerah dalam mengucurkan dana untuk program kesehatan.

Grafik 4 menunjukkan bahwa rasio pengeluaran pemerintah daerah dalam sektor bidang pendidikan terhadap total pengeluaran provinsi Jawa Barat pada 
tahun 2017 menunjukkan semua daerah memiliki persentase dibawah 20\%. Rasio Pengeluaran Pendidikan Kabupaten/Kota di Provinsi Jawa Barat terhadap total pengeluaran Provinsi Jawa Barat pada tahun 2017 masih belum mencapai 20\% alokasi anggaran pendidikan pemerintah pusat. Indikator pendidikan menjadi salah satu pengukuran kesejahteraan masyarakat sehingga tolak ukur keberhasilan pemerintah pada kesejahteraan masyarakat dapat dilihat melalui keberhasilan pendidikan (UNDP, 1996). Kabupaten Bogor memiliki rasio anggaran tertinggi dengan rasio 10,66\% sedangkan Kota Banjar menjadi persentase terendah terhadap Anggaran Belanja dan Belanja Daerah (APBD) dengan rasio 0,72\%.

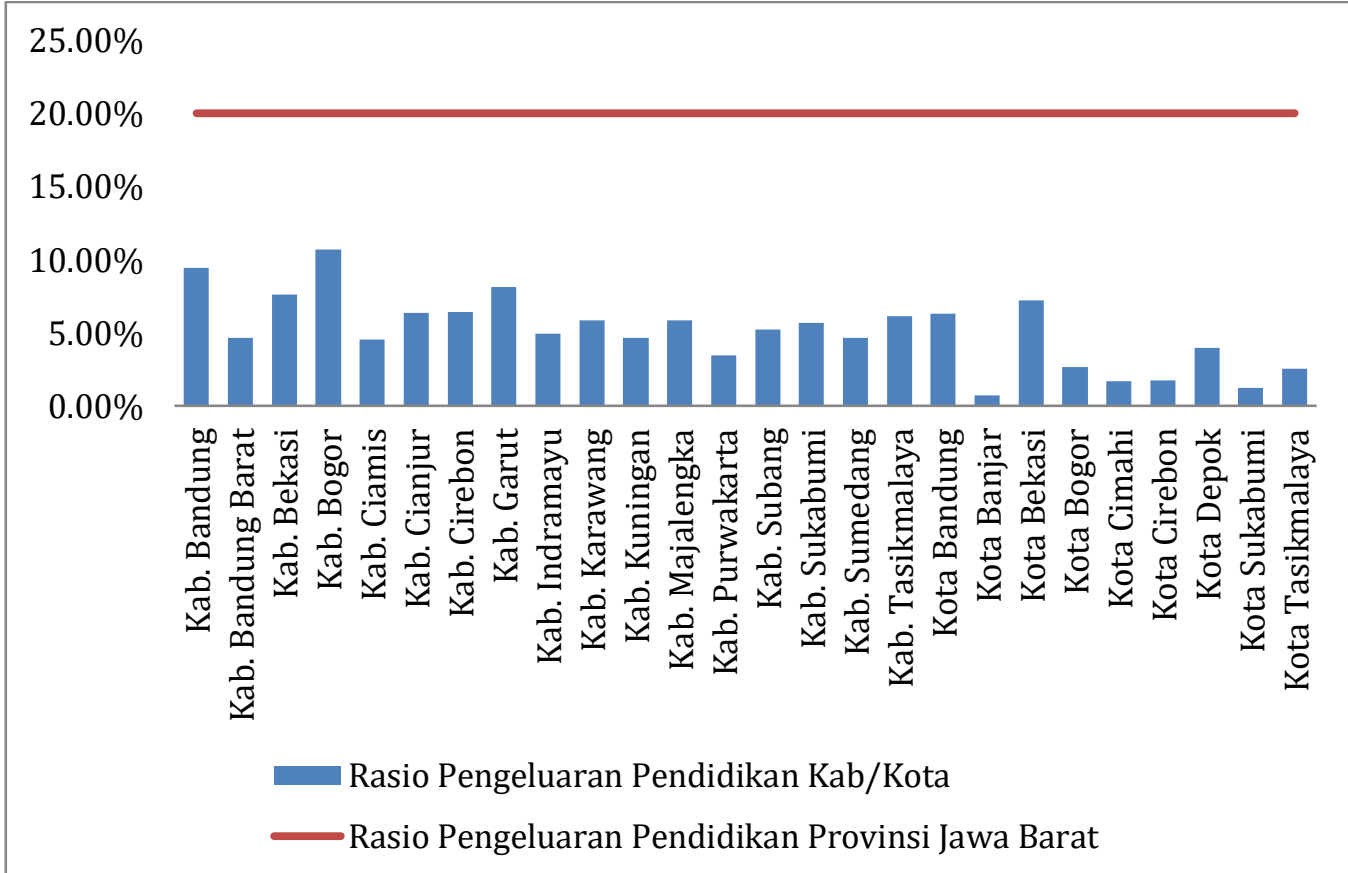

Sumber : DJPK, Kemenkeu (berbagai edisi)

\section{Grafik 4.}

Rasio Pengeluaran Pemerintah dalam Sektor Pendidikan Terhadap Total Pengeluaran Provinsi Jawa Barat dan Perbandingan Alokasi Pengeluaran Pemerintah Pusat Tahun 2017 
Selain masalah pendidikan, indikator kesehatan menjadi salah satu pengukuran kesejahteraan masyarakat sehingga tolak ukur keberhasilan pemerintah pada kesejahteraan masyarakat dapat dilihat melalui keberhasilan kesehatan (UNDP, 1996). Hal yang sama dengan pendidikan, pengeluaran kesehatan menjadi salah satu barometer peningkatan kualitas sumber daya manusia yang berdampak terhadap peningkatan pertumbuhan ekonomi. Menurut Kurt (2015) Pengeluaran Pemerintah dalam sektor kesehatan mempunyai pengaruh langsung terhadap pertumbuhan ekonomi suatu wilayah melalui layanan kesehatan, pengeluaran produk kesehatan, obat-obatan pemerintah umum.

Rasio pengeluaran pemerintah daerah untuk urusan bidang kesehatan terhadap total pengeluaran provinsi Jawa Barat pada tahun 2017 memiliki persentase dibawah 5\% untuk sektor kesehatan (DJPK, 2018). Pada rasio pengeluaran kesehatan Kabupaten/Kota di Provinsi Jawa Barat pada tahun 2017 yang memiliki rasio anggaran tertinggi yaitu Kabupaten Bogor dengan rasio 5,91\%, sedangkan Kota Banjar menjadi persentase terendah dengan rasio 0,90\%. Pemerintah Kabupaten/Kota di Provinsi Jawa Barat memiliki tingkat rasio pengeluaran kesehatan secara rata-rata $2,35 \%$ persen berada dibawah alokasi anggaran pemerintah pusat yaitu sebesar 5\% persen pada tahun 2017 yang telah tercantum dalam Undang-Undang Dasar No 36 tahun 2009 pada pasal 171 ayat (1).

Dalam mendukung pertumbuhan ekonomi di 26 Kabupaten/Kota di Provinsi Jawa Barat, terdapat beberapa indikator yaitu pendidikan melalui rata lama sekolah, indikator tenaga kerja yaitu jumlah pengangguran, indikator kesehatan yaitu angka 
harapan hidup dan jumlah belanja fungsi pemerintah dalam sektor pendidikan merupakan beberapa faktor yang dapat mempengaruhi pertumbuhan ekonomi. Pengeluaran pengeluaran dalam sektor pendidikan beberapa Kabupaten/Kota di Provinsi Jawa Barat masih belum memenuhi 20\%. Hal yang sama dalam sektor kesehatan yang belum memenuhi ketentuan yang telah ditetapkan sebesar 5\%. Oleh karena itu, tujuan penelitian difokuskan untuk menganalisis pengaruh pendidikan yang ditunjukkan oleh rata-rata lama sekolah dan angka harapan hidup, pengeluaran pemerintah sektor pendidikan dan kesehatan terhadap pertumbuhan ekonomi di 26 Kabupaten/Kota Provinsi Jawa Barat selama periode 2012-2017.

\section{METODE PENELITIAN}

Metode yang akan digunakan dalam penelitian ini adalah Panel Data Regression Model yang merujuk pada penelitian sebelumnya yang dikembangkan dari model sebelumnya (Teixeira \& Queirós, 2016; Son et al.,2013; Ngangue \& Manfred, 2015; Ecevit, 2016; Akai \& Sakata, 2002 dan Kurt, 2015). Adapun yang membedakan model ini dengan sebelumnya adalah dari aspek empiris, yaitu melakukan penelitian dalam konteks Kabupaten/Kota di Jawa Barat selama periode 2012-2017. Berikut merupakan dari spesifikasi model untuk menganalisis bagaimana faktor-faktor yang mempengaruhi pertumbuhan ekonomi.

LEgrowth $_{i t}=\beta_{0}+\beta_{1}$ Educ $_{i t}+\beta_{2}$ Llifeexpectancy $_{i t}+\beta_{3}$ Lgoveduc $_{i t}+$ $\beta_{4}$ Lgovhealth $+\mu_{i t}$

Variabel bebas yang dapat mempengaruhi variabel tidak bebas terdiri dari indikator pendidikan yang diukur oleh rata lama sekolah, kesehatan yang diukur 
oleh angka harapan hidup, pengeluaran pemerintah dalam sektor pendidikan dan pengeluaran pemerintah dalam sektor kesehatan. Variabel terikat dalam penelitian ini Pertumbuhan Ekonomi. Persamaan regresi panel data akan dilakukan pengujian asumsi klasik (Multikolinearitas, Autokorelasi dan Heterokedastisistas).

\section{HASIL DAN PEMBAHASAN}

Penentuan model terbaik dilakukan melalui dua uji yaitu Uji Chow dan Uji Hausman. Pada uji chow dan uji hausman menunjukkan bahwa nilai probabilitas lebih kecil dari tingkat signifikansi sebesar 5\%. Pada Tabel 1 menunjukkan bahwa model terbaik dalam model yang dipakai dalam penelitian ini yaitu Fixed Effect Model.

Tabel 1.

Hasil Uji Chow dan Uji Hausman

\begin{tabular}{ccc}
\hline Uji Model Terbaik & $\begin{array}{c}\text { Nilai } \\
\text { Probabilitas }\end{array}$ & Hasil Hipotesis \\
\hline Uji Chow & 0,0000 & H0 ditolak, maka FEM \\
Uji Hausman & 0,0000 & H0 ditolak, maka FEM \\
\hline
\end{tabular}

Sumber : Hasil Pengolahan

Setelah dilakukan uji model terbaik dari hasil uji chow dan uji hausman dapat disimpulkan bahwa model terbaik yaitu Fixed Effect Model (FEM). Fixed Effect Model yang digunakan dalam penelitian telah menggunakan metode pembobotan PCSE. Pembobotan ini dilakukan untuk mengkoreksi terjadinya heteroskedastisitas dan autokorelasi sehingga Fixed Effect Model yang digunakan dapat dikatakan terbebas dari pelanggaran asumsi klasik tersebut. Berikut hasil estimasi dari pendekatan model Fixed Effect Model ditunjukkan pada Tabel 2 
Tabel 2

Hasil Estimasi Model

Dependent Variabel : LEgrowth

Method Panel dan PCSE

\begin{tabular}{lcccl}
\hline \multicolumn{1}{c}{ Variable } & Koefisien & $\begin{array}{c}\text { Standar } \\
\text { Error }\end{array}$ & t-statistic & $\mathbf{p}>|\mathbf{z}|$ \\
\hline Educ & 0,371 & 0,022 & 16,87 & $0,000^{* * *}$ \\
Llife Expectancy (-1) & 0,303 & 0,135 & 2,23 & $0,027^{* *}$ \\
Lgoveduc (-1) & 0,038 & 0,012 & 3,10 & $0,002^{* * *}$ \\
Lgovhealth & 0,009 & 0,005 & 1,77 & $0,078^{*}$ \\
\hline Constant & 5,358 & 0,599 & 8,94 & 0,000 \\
\hline Log likelihood & 253,3941 & & & \\
$\mathrm{R}^{2}$ & 0,997 & & & \\
Prob > chi & & & & \\
Pseudo $\mathrm{R}^{2}$ & 0,000 & & & \\
\hline \multicolumn{2}{c}{ variabel signifikan pada tingkat kepercayaan $10 \%(*), 5 \%(* *), 1 \%(* * *)$} &
\end{tabular}

Pada hasil estimasi model diperoleh besaran $\mathrm{R}^{2}$ sebesar 0,997. Dalam hal ini menunjukkan bahwa variasi variabel independen menjelaskan variabel Pertumbuhan Ekonomi sebesar 99,7\% sedangkan sisanya sebesar 0,3\% yang dijelaskan oleh faktor-faktor lain yang tidak termasuk dalam model.

Pada uji heterokedastisitas model persamaan dalam penelitian ini memiliki nilai probabilitas yang menunjukkan lebih kecil dari tingkat signifikansi sebesar 5\% sehingga dapat disimpulkan bahwa pada penelitian ini terdapat masalah heterokedastisitas. Menurut Kmenta (1986) PCSE mengacu pada data panel yang terkena masalah heteroskedastis dan autokorelasi dikarenakan PCSE memiliki probabilitas cakupan yang mendekati nominal.

Pengujian asumsi klasik autokorelasi yang dilakukan dalam penelitian ini menggunakan Durbin Watson, hasil dari pengujian menyatakan terkena masalah 
autokorelasi sehingga regresi dalam penelitian ini menggunakan PCSE agar hasil estimasi tidak menimbulkan unbiased. Menurut Kmenta (1986) PCSE mengacu pada data panel yang terkena masalah heteroskedastis dan autokorelasi dikarenakan PCSE memiliki probabilitas cakupan yang mendekati nominal.

Pada uji multikolinearitas ini dapat menentukan apakah ada hubungan antara variabel independen satu dengan variabel independen yang lainnya sehingga dalam uji multikolinearitas ini memiliki tujuan untuk mengetahui kondisi variabel independen dalam model (Gujarati, 2012). Berikut merupakan hasil uji multikolinearitas dalam penelitian ini.

Tabel 3.

\section{Hasil Uji Multikolinearitas}

\begin{tabular}{lcccc}
\hline & Educ & Llifeexpectancy & Lgoveduc & Lgovhealth \\
\hline \hline Educ & 1 & 0.59896 & -0.07289 & 0.00060 \\
Llifeexpectancy & 0.59896 & 1 & 0.08491 & 0.00270 \\
Lgoveduc & -0.07289 & 0.08492 & 1 & 0.63666 \\
Lgovhealth & 0.00060 & 0.00270 & 0.6366 & 1 \\
\hline \hline Sumber: hasil olah data EVIEWS 9.0 & & &
\end{tabular}

Pada dilihat dalam Tabel 3 hasil dari uji multikolinearitas menunjukkan bahwa semua variabel memiliki nilai koefisien matriks kurang dari 0,8 yang menandakan bahwa dalam model tersebut variabel bebasnya telah terbebas dari multikolinearitas yang artinya tidak terjadi hubungan linear antar variabel bebas.

Variabel rata lama sekolah menunjukkan nilai koefisien sebesar 0,371621 dan memiliki hubungan yang positif dan signifikan terhadap pertumbuhan ekonomi di 26 Kabupaten/Kota Provinsi Jawa Barat. Setiap terjadi kenaikan jumlah rata lama 
sekolah sebesar 1 tahun maka akan meningkatkan pertumbuhan ekonomi sebesar 2,590349\%, dengan asumsi cateris paribus. Beberapa penelitian ini sesuai dengan penelitian Son et al., (2013) yang menunjukkan pengaruh yang positif dan signifikan terhadap GDP perkapita sehingga membuktikan variabel pendidikan merupakan pengaruh yang kuat terhadap pertumbuhan ekonomi suatu wilayah. Penelitian Teixeira \& Queirós (2016) menjelaskan pendidikan berkontribusi secara signifikan dan positif terhadap GDP perkapita dan menyimpulkan modal manusia merupakan penentu dasar pertumbuhan ekonomi.

Angka harapan hidup tahun sebelumnya menunjukkan nilai koefisien sebesar 0,303219 yang memiliki pengaruh signifikan secara statistik pada tingkat kepercayaan 99 persen terhadap pertumbuhan ekonomi di Kabupaten/Kota Provinsi Jawa Barat. Nilai koefisien variabel angka harapan hidup sebesar 0,303219 maka setiap kenaikan jumlah angka harapan hidup sebesar 1 persen maka akan meningkatkan pertumbuhan ekonomi sebesar 0,270902\%, dengan asumsi cateris paribus. Hasil dalam penelitian ini sesuai dengan penelitian yang telah dilakukan oleh Ecevit (2016) yang memberikan hasil bahwa angka harapan hidup adalah penentu dasar pertumbuhan ekonomi. Penelitian Ngangue \& Manfred (2015) menyimpulkan peningkatan harapan hidup mempengaruhi pertumbuhan ekonomi, namun signifikansi memiliki hasil yang beragam berdasarkan tingkat pendapatan seseorang.

Pengeluaran pemerintah sektor pendidikan tahun sebelumnya menunjukkan nilai koefisien sebesar 0,039421 dan mempengaruhi secara signifikan secara statistik pada tingkat kepercayaan 95 persen terhadap pertumbuhan ekonomi di 
Kabupaten/Kota Provinsi Jawa Barat. Nilai koefisien pada variabel pengeluaran pemerintah dalam sektor pendidikan sebesar 0,039421 yang menjelaskan bahwa setiap terjadi kenaikan pengeluaran pemerintah dalam sektor pendidikan sebesar 1 persen maka akan meningkatkan pertumbuhan ekonomi sebesar 0,039421\%, dengan asumsi cateris paribus. Hasil penelitian ini sesuai dengan penelitian Akai \& Sakata (2002) yang mengatakan bahwa desentralisasi fiskal berkontribusi untuk pertumbuhan ekonomi. Selain itu pengaruh pengeluaran pemerintah terhadap pertumbuhan ekonomi tidak langsung dampaknya pada peningkatan kualitas pendidikan (Cooray, 2009).

Terakhir, pengeluaran pemerintah dalam sektor kesehatan menunjukkan nilai koefisien sebesar 0,009588 yang memiliki pengaruh positif dan signifikan secara statistik pada tingkat kepercayaan 90 persen terhadap pertumbuhan ekonomi di 26 Kabupaten/Kota Provinsi Jawa Barat. Nilai koefisien pada variabel pengeluaran pemerintah dalam sektor kesehatan sebesar 0,009588 yang menjelaskan bahwa setiap terjadi kenaikan pengeluaran pemerintah dalam sektor pendidikan sebesar 1 persen maka akan meningkatkan pertumbuhan ekonomi sebesar 0,009588 \% cateris paribus. Hasil penelitian ini sesuai dengan penelitian Kurt (2015) yang menjelaskan bahwa pertumbuhan ekonomi di suatu wilayah dapat dipengaruhi secara langsung melalui pengeluaran pemerintah dalam sektor kesehatan seperti layanan kesehatan. Hasil penelitian ini sesuai dengan penelitian Akai \& Sakata (2002) yang mengatakan bahwa desentralisasi fiskal berkontribusi untuk pertumbuhan ekonomi. 


\section{SIMPULAN DAN SARAN}

Rata-rata lama sekolah, angka harapan hidup tahun sebelumnya, pengeluaran pemerintah dalam sektor pendidikan tahun sebelumnya dan pengeluaran pemerintah dalam sektor kesehatan berpengaruh positif dan signifikan secara statsitik terhadap pertumbuhan ekonomi di 26 Kabupaten/Kota Provinsi Jawa Barat tahun $2012-2017$.

Hasil dari penelitian ini, maka penulis memberikan saran untuk peningkatan dari pertumbuhan ekonomi, yaitu pemerintah harus memastikan bahwa pengeluaran pemerintah dapat teralokasikan dengan baik terhadap masing-masing daerah yang ada di 26 Kabupaten/Kota Provinsi Jawa Barat sehingga dapat dipastikan bahwa setiap penduduk yang berada di 26 Kabupaten/Kota dapat menjalankan pendidikan formal yaitu wajib belajar 9 tahun sehingga penduduk yang berada di 26 Kabupaten/Kota Provinsi Jawa Barat dapat menghasilkan sumber daya manusia yang baik dengan demikian pengangguran yang ada di 26 Kabupaten/Kota Provinsi Jawa Barat secara perlahan dapat berkurang. Terakhir, kelemahan dari kajian ini adalah periode penelitian hanya terbatas pada periode 2012-2017. Dengan demikian, diharapkan penelitian selanjutnya dilakukan dengan periode waktu penelitian sampai dengan tahun 2020 , terutama pada saat terjadi pandemi covid19 sekarang ini. Hal tersebut perlu dilakukan, mengingat kondisi pendidikan sebelum dan sesudah adanya pamdemi covid19 akan berbeda.

\section{REFERENSI}

Akai, N., \& Sakata, M. (2002). Fiscal decentralization contributes to economic 
growth : evidence from state-level cross-section data for the United States. Journal of Urban Economics, 52, 93-108.

Badan Pusat Statistik. (2017). Provinsi Jawa Barat Dalam Angka 2017. (F. Wahyu, Ed.). Badan Pusat Statistik Provinsi Jawa Barat.

Badan Pusat Statistik. (2019a). Angka Harapan Hidup. Retrieved from https://sirusa.bps.go.id/sirusa/index.php/indikator/48

Badan Pusat Statistik. (2019b). Rata Lama Sekolah. Retrieved from https://sirusa.bps.go.id/sirusa/index.php/indikator/1180

Cooray, A. V. (n.d.). The Role Of Education In Economic Growth. Proceedings of the 2009 Australian Conference of Economists, pp. 1-27.

Ecevit, E. (2016). The Impact Of Life Expectancy On Economic Growth: Panel Cointegration And Casuality Analyses For OECD Countries. The International Journal of Social Science, 16(1).

Gujarati, D. (2012). Dasar - Dasar Ekonometrika Edisi 5. Jakarta: Salemba Empat.

Kmenta, J. (1986). Elements of Econometrics (2nd ed). New York: Macmillan.

Kurt, S. (2015). Government Health Expenditures and Economic Growth: A FederRam Approach For The Case of Turkey. International Journal of Economics and Financial Issues, 5(2), 441-447.

Ngangue, N., \& Manfred, K. (2015). The Impact Of Life Expectancy On Economic Growth In Developing Countries. Asian Economic and Financial Review, 5(4): 653-. Retrieved from http://www.aessweb.com/journals/5002

Son, L., Noja, G. G., Ritivoiu, M., \& Tolteanu, R. (2013). Education and Economic Growth: An Emperical Analysis of Interdependenciesand Impact Based On Panel Data. Timisoara Journal of Economics AndBusiness, 6(1), 19.

Teixeira, A. A. C., \& Queirós, A. S. S. (2016). Economic growth, human capital and structural change: A dynamic panel data analysis. Research Policy, 45(8), 1636-1648. https://doi.org/10.1016/j.respol.2016.04.006

UNDP. (1996). Human Development Report 1996. (M. Gerald Quinn, Quinn Information Design, Cabin John, Ed.). United Nations Development Programme. 